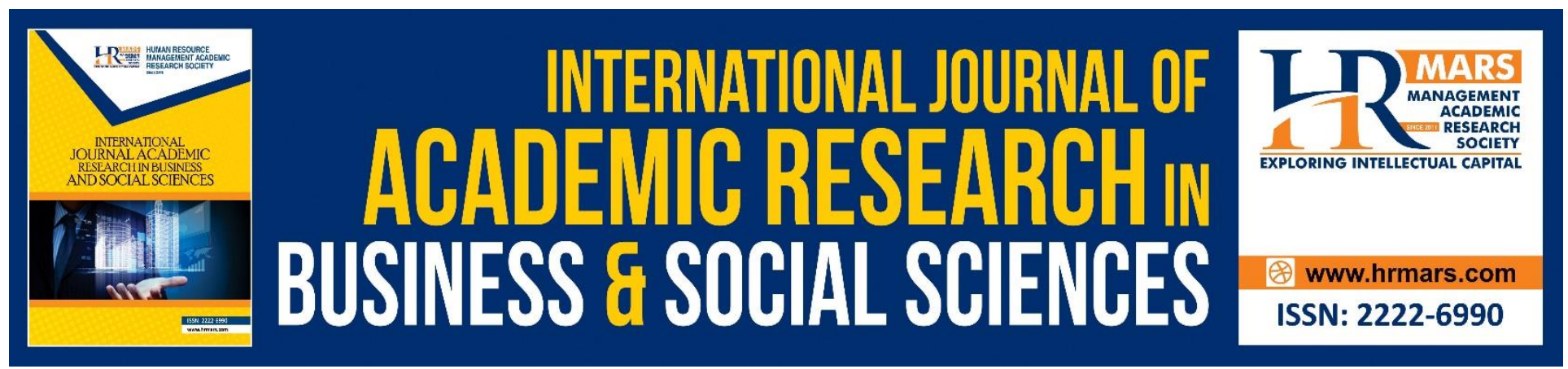

\title{
The Impact of Amanah on Individual Manners and the Society
}

Arena Che Kasim, Mawil Izzi Dien, Shukriah Che Kasim, Jamiah Manap

To Link this Article: http://dx.doi.org/10.6007/IJARBSS/v10-i9/7854 DOI:10.6007/IJARBSS/v10-i9/7854

Received: 08 June 2020, Revised: 11 July 2020, Accepted: 15 August 2020

Published Online: 28 September 2020

In-Text Citation: (Kasim, et al., 2020)

To Cite this Article: Kasim, A. C., Dien, M. I., Kasim, S. C., \& Manap, J. (2020). The Impact of Amanah on Individual Manners and The Society. International Journal of Academic Research in Business and Social Sciences. 10(9), 629-640.

Copyright: (C) 2020 The Author(s)

Published by Human Resource Management Academic Research Society (www.hrmars.com)

This article is published under the Creative Commons Attribution (CC BY 4.0) license. Anyone may reproduce, distribute, translate and create derivative works of this article (for both commercial and non-commercial purposes), subject to full attribution to the original publication and authors. The full terms of this license may be seen

at: http://creativecommons.org/licences/by/4.0/legalcode

Vol. 10, No. 9, 2020, Pg. 629 - 640

http://hrmars.com/index.php/pages/detail/IJARBSS

JOURNAL HOMEPAGE

Full Terms \& Conditions of access and use can be found at http://hrmars.com/index.php/pages/detail/publication-ethics 


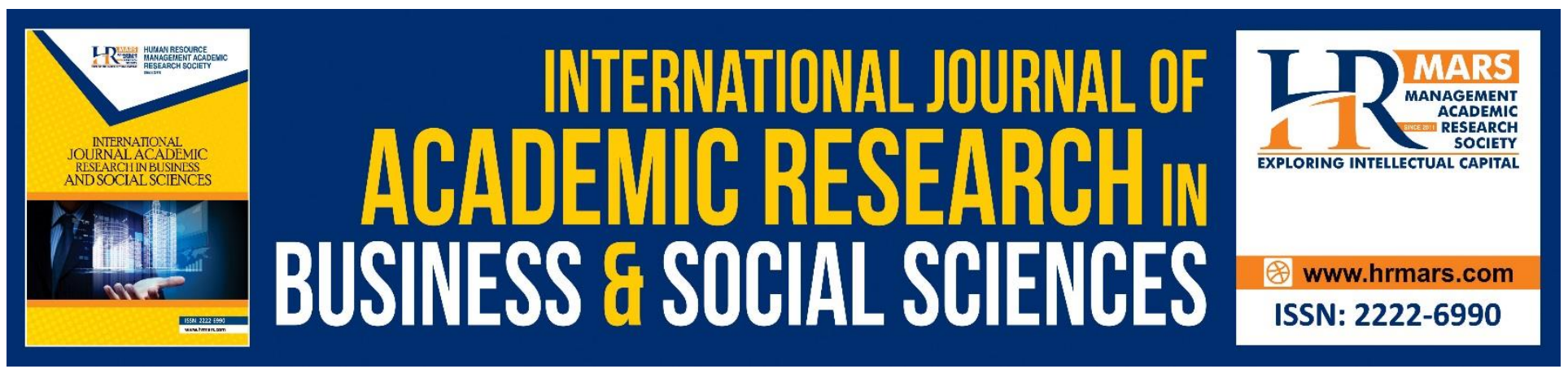

\title{
The Impact of Amanah on Individual Manners and The Society
}

\author{
Arena Che Kasimª, Mawil Izzi Dien ${ }^{\mathrm{b}}$, Shukriah Che Kasim, Jamiah \\ Manap $^{a}$ \\ a Centre for Research in Psychology and Human Well-Being, Faculty of Social Sciences and \\ Humanities, The National University of Malaysia, Bangi 43600, Malaysia, b School of Religious \\ Studies, Theology and Islamic Studies, University of Wales Trinity Saint David, Wales, UK, c Academy \\ of Islamic Studies, Universiti of Malaya, Nilam Puri, Kelantan
}

\begin{abstract}
The ethical and social dilemmas now faced by on a global basis by individual countries are becoming more and more complex. Especially worrying is the escalation in instances of malpractice, misconduct and corruption among public civil servants, and Malaysia is no exception irrespective of age, race or religion. This study therefore sets out to examine and analyse (from a qualitative perspective) why such social and ethical problems are proliferating in Malaysia. Findings showed that the principles of amanah (a trustworthy character) can form the basis for a human capital development model which strives to follow the perfect example of the Prophet صلى الله عليه وسلم.
\end{abstract}

Keywords: Amanah, Impact, Manners, Individual, Society.

\section{Introduction}

For more than a decade, much of the Muslim world has experienced the impact of Islamic revivalism and it has emphasised upholding Islamic Laws and the assertion of Islamic Values in government administration and politics (Shaare Endot 1995) Amanah is an attribute which is hardly to incurred and tremendous effects as a result of this nature is described by Allah in the Qur'an (Al-Ahzab: 72). Malaysia as one the country which is known as the Islamic country also put a lot of effort in establishing Islamic values among the people. This article attempt to discuss about the implementation of amanah which is also one of the Islamic value to the society in order to reduce if not eliminate the problem of malpractice, misconduct and corruption among professionals in Malaysia. It is believed that this research is important to indicate one of the solutions and alternative for the stated problems. There are a lot of researches done on the important of amanah in every aspect of life. 
INTERNATIONAL JOURNAL OF ACADEMIC RESEARCH IN BUSINESS AND SOCIAL SCIENCES Vol. 10, No. 9, 2020, E-ISSN: 2222-6990 @ 2020 HRMARS

\section{Literature Review}

The research which has been done by Bews and Rossouw (2002) with regards to the role of business ethics in facilitating trustworthiness concluded that there is no clear evidence of a relationship between the task of ethics in promoting trustworthiness but, on the other hand, trust can be easily abused if people are behaving in unethical character. Meanwhile, Slemrod and Katuscak (2005) had conducted research to measure the degree of attitudes towards trust and trustworthiness, which was evaluated and indicative the relationship between individual income and self-reported attitudes. This anticipated how these relationships are negotiated by the average level of trust and trustworthiness in the country and it highlights that trustworthiness accrued with a payoff with the average level of trust in a given country.

According to Zaheer, McEvily and Perrone (1998), who conducted research on a conceptual challenge in exploring the role of trust in inter-organisational relations and the effects on interorganisational exchange, translating an inherently individual level concept - trust - to the organisational level found that interpersonal trust and performance really matter, even though some of the respondents did not consider that there was much relatedness. Besides that, Hodson (2004) concluded that trustworthiness should become an integral part of the organisation and an important precondition and the main factor in upgrading the effort and initiative of the employees.

Zaheer and Zaheer (2006) examined the role of trust in international collaboration, based on the idea that not only does the level of trust differ across international borders, but also the nature of trust and cultural and institutional support for the trust may vary across different national contexts. Collaboration partners from different countries therefore tend to bring both the concept of symmetry or asymmetry of trust to business relations (Zaheer and Zaheer, 2006). Becerra and Gupta (2003) in their research intended to see the effects on trustor and trustee, based on the moderating impact of communication frequency. The findings confirmed that the effect of both the trustor as well as trustee characteristics' on the level of perceived trustworthiness is moderated by the frequency of the communications between the two parties.

According to Caldwell and Clapham (2003), although trust has been widely acknowledged as an important component of the relationship, and an important element for the success of the organisation, the literature reflects that trust and confidence is seen from a different perspective, and this is inconsistent. Belief has been identified as a prerequisite for the development of trust. Furthermore, Amirin (2007) had concluded that leadership in Islam is a type of trust (amanah), whereby it represents a psychological contract between the leader and his followers, which means that $\mathrm{s} /$ he will try his/her best to give support and guidance, to protect and treat them in a fully just way.

Amanah or trust and trustworthiness plays a vital role in guiding and being a guideline or benchmark to others in any field of peoples' social and personal activities. Due to that, all mankind should behave in an amanah manner, to ensure good and harmony throughout their daily life, regardless of time and place. 
INTERNATIONAL JOURNAL OF ACADEMIC RESEARCH IN BUSINESS AND SOCIAL SCIENCES Vol. 10, No. 9, 2020, E-ISSN: 2222-6990 @ 2020 HRMARS

Trust is a basic element of functioning relationships in organizations. Employees in organizations create trustworthiness by their daily behaviour and actions. Feelings of insecurity appearing in workplaces may be often a reason for atmosphere- related problems such as teasing, conflicts, and disputes (Savolainen, \& Hakkinen, 2011). Othman (2008) had formulated the development and validation of the inventory. The most important core values that form this personality inventory are Ibadah, Amanah and IIm, and these three components have been selected for compilation as a tool of assessment, which has been named as the Ummatic Personality Inventory. This inventory was done with the intention of finding the solution to the problem of misbehaviour amongst the youth and corruption issues amongst the adults in their professional and personal lives.

Khan (2003) discussed the question of high morals and ethics, especially amongst graduates, in the performance of trust and responsibility held. Besides presenting the interests of morals and ethics in the world of work, he also discussed human responsibilities and the relevance of the inheritors, or caliph of a life passed, the importance of values in shaping the civil generation was brought up to emphasise the importance of the positive nature of such practices as sabar (patience), syukur (gratitude), amanah (trustworthiness), adil (fairness) and benar (truth). Overall, character and ethics are among the things that should be emphasised to create a professional individual who has excellent behaviour and conduct which fit to the career field.

Meanwhile according to Bhatt and Sinnakkannu (2008), the concept of Ar-Rahn (Islamic pawn in Malaysia) is generated with a combination of four elements or concepts, and one of the concepts is Wadiah Yad-Amanah (Trustworthiness) which means that the borrower is required to produce returnable collateral to ensure repayment of the loan. The borrower, on the other hand, entrusted the lender to look after the belongings during the loan period. Ghazali (2009) found that attitudes toward behaviour, subjective norms and perceived behavioural control mediated the relationship between the scales of personal and religious accountability in order to pay zakat (alms). The scale of religion measured by religious education, religious faith and worship (religious practice) meanwhile, personal accountability is measured by trustworthiness and sacrifice.

Furthermore, there was a study aimed to demonstrate the concepts of leadership based on the characteristics of those Mottaqin (obedience) according to the Qur'an. The concept of Taqwa has been identified as having two distinct components; spirituality and responsibility. Spirituality has three dimensions; faith, ritual and repentance; meanwhile responsibility has six dimensions; emotional control, charity, forgiveness, integrity, patience and justice. The results showed that the leadership influences the effectiveness of piety, in which a spiritual dimension, which is faith, and the three dimensions of responsibility, charity, integrity, and emotional control, makes it possible to determine (predicate) Effective Leadership in Business, while trust (amanah) was found as a positive influence on leadership effectiveness. In addition, trust was found to mediate the relationship between faith and Leadership Effectiveness in Business in full; and trust (amanah) was also found to be a partial mediator in the relationship between responsibility and effective Leadership. Practical implications of the study include the design of training programs aimed to increase the level of spiritual leaders, and to foster self-restraint in the organisational culture (Mohsen, 2007). 


\section{Method}

This research is largely qualitative in nature, as it seeks the answer to the question of why malpractice, misconduct and corruption levels are increasing and how to overcome the problem from the perspective of Islam based on the Holy Qur'an and the seerah of the prophet Muhammad صلى الله عليه وسلم

\section{Results and Discussions}

The impact of amanah in the society is starting with the cultivating it in the individual. In general, the effect of amanah on manner and self can be divided into three different categories which are as follows:

\section{i. Individual Righteousness and Integrity}

Individual righteousness and integrity is considered as part of human inner self which mean that it is the sources which can grow the various types of characters and can contribute to the goodness and also the wickedness in speaking, actions and behaving. In fact, everyone has two different personalities which are always contradicts between both of it which known as the good and the bad. God as the Creator knows the best and revealed the guidance and guideline to follow and also mind $\left({ }^{c} a q l\right)$ to choose the right conduct.

As a human being, the individual has a tendency to be materialistic, satisfy their lusts and very keen to compliment and praised. This situation happened according to psychologists because there was part of the self which is unconscious. Meanwhile, akhlaq or ethics or moral scholars said that inner spiritual power has a great influence upon the lifestyle and human behaviour as well as his abilities (Al-Husayn, 2003: pp. 234-235). In fact, less than 50\% of human conduct appears based physically influences, most of them are internally or mentally. This character either good or bad will be identified through their daily behaviour. This is because the action which appears is a reflection of the inner needs or strength.

Ali Fikri had affirmed the link of amanah with both the psychological and behavioural by saying that amanah is the king or the chief in psychology and its impact is justice and respects the rights of others who differ in terms of religion and culture (Al-Husayn, 2003: p. 235).

From the statement given, it shows the impact of amanah in keeping individual righteousness and integrity in the right way and avoiding from being wrong doers is really significant. As being said by Abu Hamid al-Ghazali: 'in fact for oneself is near and far, and their nearest is due to their knowledge and gain advantages from it, and far because of their ignorance and humiliation received cause by it (Al-Ghazali, 2000).

In fact, for every mankind, he has to protect himself from being as wrongdoers or bad deeds whenever he faces and identify it and this sign resemble the call for justice and truth. The wicked self can only spread disruption and disorders in the society and government (Muhammed Al-Ghazali, 1983). Furthermore, amanah (trustworthiness) will not be enforced until upheld his tongue and the tongue will not be enforced unless upright heart (Al-Husayn, 2003). Once, amanah already captured the life of the first generation, the impact of it is very big in themselves and their behaviour or 
INTERNATIONAL JOURNAL OF ACADEMIC RESEARCH IN BUSINESS AND SOCIAL SCIENCES Vol. 10, No. 9, 2020, E-ISSN: 2222-6990 @ 2020 HRMARS

character. That is why the reform of the self is the first foundation pillar of the supremacy of virtue in this life (Muhammed Al-Ghazali, 1983). In fact, self and the nature of humanity are always urged to do good deeds.

Mankind has been reminded that nothing in this world can change them unless they themselves put every effort to change, and for Muslims, they believe in the Day of Judgement in the Hereafter whereby they will be judge base on their deeds in this worldly life.

Individual righteousness and integrity can be discuss further in two categories which are firstly, truthfulness in dealing whereby it refers to the acceptance of rights and receiving a nice compliments or credit from the people surrounding and the most important is from God. Secondly, flourish and widespread warmth, love, intimacy and friendliness because this feeling can creates a close and strong binding relationship among individuals in the community and thus nourish the love and mercy of God. This will lead to the self-clarity and love kindness to others (Al-Husayn, 2003).

As a conclusion, amanah plays three important roles in make sure that people behaving in the right way which are firstly, amanah act as a leader in leading other faculty to behave in the right way, then it acts as a motivator or checker (check and balance) in whatever action perform by mankind by correcting and asking or blaming whenever mistakes being done by the physical parts, and lastly there is no contradict when we are acting in amanah with the profit or benefit which human can receive if they behave in different way.

\section{ii. Sincerity (al-Ikhlas) in Performing Duties and Responsibilities}

The sincerity is the most important point in performing duties and demand in religious. There is a lot of evidence from the Qur'an and hadith of the Prophet discussing about the importance of sincerity. Sincerity is the most vital one in securing the good deeds. In fact, the culmination of trust affecting the construction of every human life is guided by faith in the discharge of all responsibilities and duties (Al-Husayn, 2003).

It is true that sincerity acts to fosters individual thought and the right conduct in his practices, and pleased with it furthermore it prevents him from precision and splendour. Sincerity in performing duties and responsibilities is doing the job and tasks given to them with full of efforts. In other words, he fulfils and completing his duties without any intention of being praised and compliment, to show off, or even proud of his effort and sincerity.

It is possible to say that, sincerity is something which is should be there to ensure the existing of amanah among Muslims in particular and others generally. It is because its leads to good deeds which also responsible for righteousness and integrity among mankind (Al-Husayn, 2003).

In fulfilling the sincerity in performing duties and responsibilities it should be contains of two elements which are discharge of its responsibilities and duties earnestly and holds extremely well. By being a discharge of the responsibilities and duties earnestly, it can give the impact into the growth of internal control which is having a very high impact in the practising of amanah in oneself. In fact, 
INTERNATIONAL JOURNAL OF ACADEMIC RESEARCH IN BUSINESS AND SOCIAL SCIENCES Vol. 10, No. 9, 2020, E-ISSN: 2222-6990 @ 2020 HRMARS

every Muslims in particular should perform all the responsibilities with all the capabilities because they will be asked in here after by Allah (Al-Husayn, 2003).

Islam did ask all the people to holds all the responsibilities and duties extremely well because it is the most important factor which can bind the community together and for the sake of humanity in general. This is the reason for the Muslims in particular to behave in amanah (Al-Husayn, 2003). By performing amanah, it can lead to strengthen the bonding of mental and spiritual among the community.

Besides that, every mankind should be responsible in every action they perform because they will be asked all the deeds which has been done throughout their life either in front of Allah or other mankind. This is shows the relation between responsibilities and amanah since this behaviour is leads to the consequences in the future. By the way, each mankind will be entrusted merely his ability and he will not assume responsibilities that cannot afford to incur.

The responsibilities which should be borne by all mankind is mainly divided into two parts which known as individual responsibilities and responsibilities towards his community. Individual responsibilities relatively the same with regards to the type of responsibilities he should adhere to for instance, as a child he has some responsibilities towards his parents, his family. Then, if he is appointed as a leader or the ruler of the country he will borne the responsibilities towards the people under his rule which is known as responsibilities towards the people under his rule (Al-Husayn, 2003) as the Prophet Muhammad صلى الله عليه وسلم has declared in one of the hadith (Mishkat al-Masabih, Vol.2, p.567-568):

Every one of you is a guardian and every one will be asked about his subjects, the leader is a guardian. He will be asked about his subjects. A man is a guardian of the persons in his household. He is answerable about them. A woman is the guardian of her husband's house. She will be asked about her responsibility. The servant is the guardian of the articles of his master. He is answerable about the responsibility of his.

The fulfillment of the trust does not only happen from top to bottom but also happens from the bottom up, if the trust must be fulfilled by the parents, the trust must also be fulfilled by the child as well. Islam encourages its followers to always be obedient and humble to their parents in an effort to educate the nature of responsibility and trust in children towards their parents.

On top of that, the responsibility towards the parents should be at the highest ranking or at the utmost important than to be obeyed and adhere by each and every individual. Every mankind should realise that they will be liable to any acts and responsibilities granted upon them without exception. Due to that, they have to be very cautious on any act they performed in this life.

\section{iii. Approaching Happiness and Success through Amanah Practice}

The first two points is dealing with the impact from the material perspective or from the seen aspect but the last one is dealing with the impact on the inner aspect that is the people who are practising amanah, they will achieve happiness and blessing from God. 
There is no doubt that every human being regardless of whatever race or religion they are longing for success and a happy life all the time. Happiness can facilitate all human efforts and businesses day by day, year by year and this fact was agreed by mostly philosophers and intellectuals, professors of sociology and psychology (Al-Husayn, 2003). Mankind will achieve the happiness impact of practising the amanah and this situation can be accessed from two angles of their lives that are living in a world of happiness and success and blessing in the hereafter. As a Muslims, we believe that mankind is the noblest creature has been created by God as compared to others as being stated in Qur'an (Al-Isra;(17:70).

The distinction and honour conferred by Allah on man are recounted in order to enforce the corresponding duties and responsibilities of man. He is raised to a position of honour above the senseless creation: he has been granted talents by which he can transport himself from place to place by land, sea and now by air: all the means of the sustenance and growth of every part of his nature are provided by Allah, and his spiritual faculties (the greatest gift of Allah) raise him above the greater part of Allah's creation (Ali, 1989).

Basic foundation of raised mankind at the higher level compared to other due to their responsibilities and tasks given upon them in this worldly life. They were not created for nothing but to uphold a lot of responsibilities and duties towards God. Happiness in this worldly life can be achieved only by performing amanah in daily life.

The impact of practising amanah on happiness in worldly life such as they will be love by the people surrounding due to the character and practice by them. The most important is that they will be love by Allah and the prophets it is because by doing good deeds towards the other creatures will help them to gain from Allah and His messengers (Al-Husayn, 2003). By accepting the truly love from Allah and the Prophets, they will have the sense of richness in their feeling because they do not have to feel afraid of other or become dependent to the other people but they have Allah who will shower them with all the love they need for. Definitely the richness will lead people to become happy all the time.

They will be protected by Allah for their amanah practices. Allah will keep all of their belonging such as families, properties, status and prides from being harm by the other people. This protection is promised by Allah from this worldly life till the end of their life (Al-Husayn, 2003). This promise will prolong to the life in the hereafter.

\section{The Sociological Effects}

Furthermore, the individual who are well developed with noble character definitely will contribute high impact upon the sociological effects for the surrounding as well.

\section{i. The Development of Noble Character within Society}

It is understandable that mankind has a tendency to get a happy life in the community. The basic needs of human psychology are in substance necessary to meet and integrated with other people in their daily lives. To get together and having a lasting relationship with others, each and every one of them should behave in the most acceptable manners that is having good moral conduct or akhlq al- 
INTERNATIONAL JOURNAL OF ACADEMIC RESEARCH IN BUSINESS AND SOCIAL SCIENCES Vol. 10, No. 9, 2020, E-ISSN: 2222-6990 @ 2020 HRMARS

karimah. (sifat al-mahmudah) and according to Mustafa al-Sibai (p.103) commitment towards social responsibility is their better performance indeed (Al-Husayn, 2003).

Allah has said in the Qur'an which means that (Al-Ma'idah; (5:2):

'...Help ye one another in righteousness and piety, but help ye not one another in sin and rancour:...'

Allah remind all the people to help each other in doing the good and beneficial contribution but never give any assistance in related to the bad deeds and evil. The Prophet also reminded his followers by saying that the reward is the good character and sin is what there is in the heart of someone and he hates to share and disclose to all people.

Amanah is a manifestation of all the good deeds showed by the community. If all of the community members are performing and practising all the good moral conducts and hate the bad moral conducts no matters what it is from happened within the society, it is believed that the amanah behaviour will prosper in the society.

By practising this character, we can gain the feeling of safety, relieved and feeling of belonging and will try the best to avoid from conflict, hatred and shackles. The evidence of feeling safety and relieved by receiving community cohesion has been said by Allah in Qur'an (Al-Ḥashr, (59: 9).

This verse showed to us that if we practice the good and generous hospitality, we definitely can create the feeling of comfort and welcoming even though we have to leave our belonging. This situation has been read about what had happened to the Muhajirunwho left their property in Makkah after accepting Islam and come to Madinah, they received very warm welcome from the Anșar. Furthermore, all these feeling can lead people to purify their souls and contribute to the practise of amanah (Al-Husayn, 2003).

Despite that we will also received the sense of brotherhood and mutual assistance between the people surrounding by practising amanah. Far from that this character can help in disseminating love among the community in the social groups and try to achieve trust of brotherhood and to advocate for better regardless of how many levels of society (Al-Husayn, 2003).

\section{ii. Mutual Trust within Society}

A mutual trust is the nature of the person holds with him whether in conversation or behaviour and conduct (Al-Jurjani, Al-Ta'rifat, p.99). This is a one of the sign of a person behaving in the amanah behaviour or character. The person who is behaving with amanah will always acting and behaving in such ways throughout his life regardless of time and condition.

The nature is one of the most important akhlq or moral which is the basic foundation for the relation building among people in the society. It also can affect the relationship between individual in the society. The relationship in the society is important because of the needs and wishes in daily life whereby the individual cannot survive without the support and relation between them in the society. 
INTERNATIONAL JOURNAL OF ACADEMIC RESEARCH IN BUSINESS AND SOCIAL SCIENCES Vol. 10, No. 9, 2020, E-ISSN: 2222-6990 @ 2020 HRMARS

The seerah of the prophet to be the saviour arguments to set the Hajarul Aswad (Black Stone) in the Baitullah proves the honesty is one of the Prophet's character can attract people's trust at that time to make him as a facilitator in their disputes. He had earned the title of al-Amin caused this noble trait can solve the problems properly (Al-Mubarakpuri, tt.).

Thus, the real amanah is the belief among all of the beliefs and the complex social relationships that contribute to the mutual trust among community members. Without this character it is hard to build mutual trust among people in community because the lasting relationship is believed based on the trust and belief among themselves.

Among the most essential things in promoting sense of mutual trust in society is by having the mutual respect for the efforts of others. It is believed that, this situation can help the individual from behaving in individualistic and isolated and becoming as a person who has respect towards other people surrounding him. Islamic teaching never allowed Muslims to make or create harm towards other people and society.

The impact of the mutual respect for the effort of others can be divided into two that is mutual benefit between men from one another is the same regardless of they are from dessert or big city. Muslim community has been mixed in the field of science, politics and economics and other fields that emphasize the synthesis of a strange life. Furthermore, the mutual respect for the efforts of others also can lead to achieve common benefits. It is a real sense of mutual respect, a sense of self which is always associated with the nature of the external benefits to others (Al-Husayn, 2003).

As being believed by mostly people that, it is hard to live alone in this world without being together with others. We need friends and relatives to be with in sharing all the joy and sorrow throughout our journey in this world.

\section{iii. The Manifestation of Civilised Society}

What is exactly mean by the existence of a comprehensive social system of their life and everything that is they themselves possess and is available surrounding them? Amanah is at the top level of the social system among good deeds and good morals in the formulation of public life (AlHusayn, 2003). This good deeds and amanah will benefit another society as well. The most important is that the people in the society can implement the concept of ordaining of good (al-amr bi al-makruf) and forbidding of evil (al-nahy anil al-munkar).

All the Muslims are expected to continue to practice the amanah themselves and faith, and telling the truth about what they believe in, and the time regulations of civilization and the emergence of the desired. It is clear that the impact of keeping and performing amanah in manifesting a civilised society come into two ways that are; the strength of society and civilization whereby Islam has called for society building as a basic for justice and strength.

Revelation is also like a balance, an instrument placed by Allah in our hands, by which we can weigh all moral issues, all questions of right and wrong in conduct. The Balance may refer to the God-given 
INTERNATIONAL JOURNAL OF ACADEMIC RESEARCH IN BUSINESS AND SOCIAL SCIENCES Vol. 10, No. 9, 2020, E-ISSN: 2222-6990 @ 2020 HRMARS

faculty by which man can judge between right and wrong. Iron is the most useful metal known to man and its stands as the sign of Strength, Power, Discipline, and Law's sanctions (Ali, 2000).

Behaving in amanah can become as a reflect image to the community features and as the sign progress of the civilisation for the said community. Far from that, it can contribute to the spread and sharing on the beauty of Islam among others which is indirectly can raise the word of Islam and the emergence of right among the people all over places (Al-Husayn, 2003). On the authority of Abu Hurayrah (may Allah be pleased with him) that the Messenger of Allah صلى الله عليه وسلم said: Allah the Almighty says: 'My faithful servant's rearward from Me, if I have taken to me his best friend from amongst the inhabitants of the world and he has then borne it patiently for My sake, shall be nothing less than Paradise' (Ibrahim \& Johnson-Davies, 1990).

\section{Conclusion}

When people are practising amanah, they will achieve the happiness in this worldly life and the hereafter. It is being said that the worldly life is the place where we planted our plants and the benefit we will be harvested in the hereafter. It means that, the goodness which we provided today will be seen and reward by Allah in the hereafter. Furthermore, the individual who are well developed with noble character will contribute high impact upon the individual and sociological effects for the surrounding.

\section{References}

Ali, A. Y. (1989). The Holy Qur'an Text, Translation and Commentary. New Revised Edition. Maryland, USA: Amana Corporation.

Ali, A. Y. (2000). The Holy Qur'an, $1^{\text {st }}$ Published 1934, $1^{\text {st }}$ published by IPCI 1999, Reprinted 2000, Birmingham, England: IPCl: Islamic Vision.

Khan, A. N. M. A. (2003). Graduan Berakhlak Mulia dan Beretika Pemangkin Generasi Madani. Jurnal Kemanusiaan, 2003, pp.20-33.

Amirin, T. M. (2007). Kepimpinan yang Amanah. Dinamika Pendidikan, No. 11, Th.XIV/ Mei 2007, 1, 6-11.

Becerra, M., \& Gupta, A. K. (2003). Perceived Trustworthiness within the Organization: The Moderating Impact of Communication Frequency on Trustor and Trustee Effects. Organization Science, Vol. 14, No. 1, Jan - Feb 2003, 32-44.

Bhatt, P., \& Sinnakkannu, J. (2008). Ar-Rahnu (Islamic Pawning Broking) Opportunities and Challenges in Malaysia. 6th International Islamic Finance Conference 2008 Peer Reviewed Paper, 2008. p.5.

Caldwell, C., \& Clapham, S. E. (2003). Organizational Trustworthiness: An International Perspective. Journal of Business Ethics, Vol. 47, No. 4, Business Ethics in Transitional Economies: Special Issue from the International Conference, Nov 2003, pp. 349-364.

Ghazali, A. R. (2009). Kesan Tahap Keagamaan dan Akauntabiliti Peribadi terhadap Niat Membayar Zakat Perniagaan di Kalangan Kontraktor Perniagaan Tunggal Pulau Pinang. 2009, Master Thesis, Universiti Sains Malaysia.

Hodson, R. (2004). Organizational Trustworthiness: Findings from the Population of Organizational Ethnographies. Organization Science, Vol. 15, No. 4, Jul - Aug 2004, pp. 432-445. 
INTERNATIONAL JOURNAL OF ACADEMIC RESEARCH IN BUSINESS AND SOCIAL SCIENCES

Vol. 10, No. 9, 2020, E-ISSN: 2222-6990 @ 2020 HRMARS

Al-Jurjani, Al-Ta'rifat. (p.99) cited in Abdul Latif bin Ibrahim bin Abdul Latif Al-Husayn, Dr. (2003). AlAmanah fi al-Islam Wa Atharuha fi al-Mujtama'. $1^{\text {st }}$ Edit. Saudi Arabia: Dar Ibn al-Jauzi.

Mohsen, N. R. M. (2007). Leadership from the Qur'an relationship between Taqwa, Trust and Business Leadership Effectiveness. (2007, Phd Thesis, Universiti Sains Malaysia).

Al-Ghazali, M. (1983). Muslim Character, A. Karim Shaikh (Trans), Bombay: Hindustan Publications.

Othman, N. (2008). The Development and Validation of the Ummatic Personality Inventory, A dissertation submitted in partial fulfilment of the requirements for the degree of Doctor of Philosophy at Institute of Education, International Islamic University Malaysia. May 2008.

Sabhiy, A. R. 'A. (1990). Al-Mucjam al-maudhuci li-ayat al-Qur'an al-Karim. Al-Qaherah: Dar alFadhilah.

Savolainen, T., \& Hakkinen, S. (2011). Trusted to Lead: Trustworthiness and its Impact on Leadership. Open Source Business Resource, (March 2011).

Endot, S. (1995). The Islamisation Process in Malaysia the Government Approach to Islamisation, the Impact of the Process in Organisations, and the Manifestation of Islamic Values in the Workplace. Unpublished PhD Thesis which has been submitted to Postgraduate School of Studies in Management and Administration, University of Bradford.

Slemrod, J., \& Katuscak, P. (2005). Do Trust and Trustworthiness Pay Off? The Journal of Human Resources, Vol. 40, No. 3, Summer, 2005, pp. 621-646.

Zaheer, A., McEvily, B., \& Perrone, V. (1998). Does Trust Matter? Exploring the Effects of Interorganizational and Interpersonal Trust on Performance. Organization Science, Vol. 9, No. 2, Mar - Apr 1998, pp. 141-159.

Zaheer, S., \& Zaheer, A. (2006). Trust across Borders. Journal of International Business Studies. Vol. 37, No. 1, Jan 2006, pp. 21-29. 